Impairment of the hematological response and interleukin-1 $\beta$ production in protein-energy malnourished mice after endotoxemia with lipopolysaccharide

R.A. Fock, M.A.R. Vinolo, S.L. Blatt and P. Borelli

The Brazilian Journal of Medical and Biological Research is partially financed by

\section{Q QNCNP}

Ministério da Ciência e Tecnologia

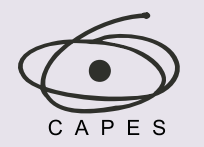

Ministério da Educação
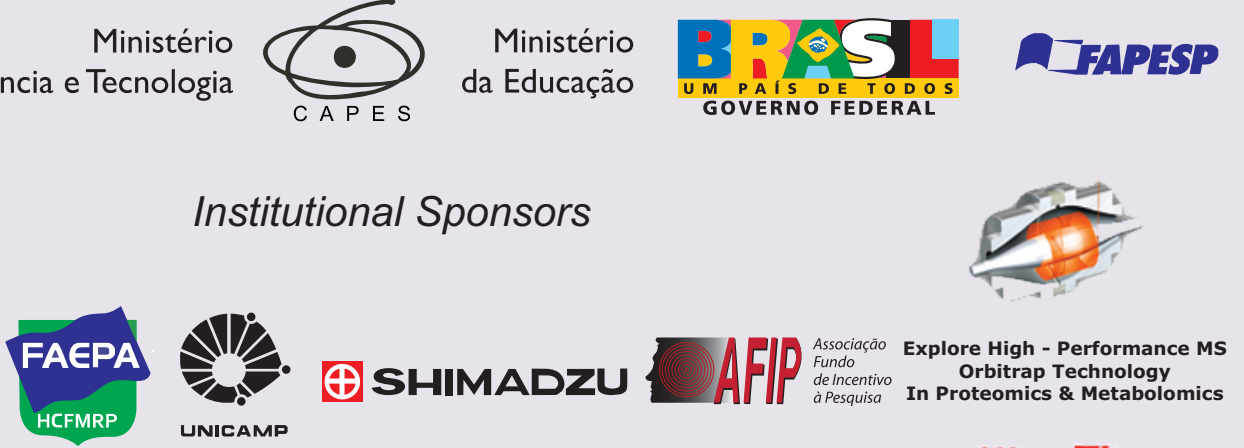

Institutional Sponsors

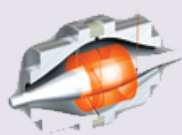

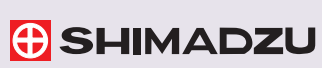
UNICAMP
TAPESP

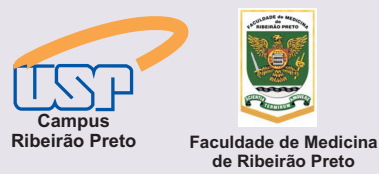




\title{
Impairment of the hematological response and interleukin-1 $\beta$ production in protein-energy malnourished mice after endotoxemia with lipopolysaccharide
}

\author{
R.A. Fock, M.A.R. Vinolo, S.L. Blatt and P. Borelli \\ Laboratório de Hematologia Experimental, Departamento de Análises Clínicas e Toxicológicas, \\ Faculdade de Ciências Farmacêuticas, Universidade de São Paulo, São Paulo, SP, Brasil
}

\begin{abstract}
The objectives of this study were to determine if protein-energy malnutrition (PEM) could affect the hematologic response to

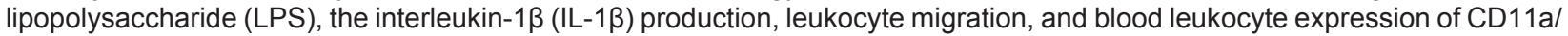
CD18. Two-month-old male Swiss mice were submitted to PEM $(\mathrm{N}=30)$ with a low-protein diet (14 days) containing $4 \%$ protein, compared to $20 \%$ protein in the control group $(\mathrm{N}=30)$. The total cellularity of blood, bone marrow, spleen, and bronchoalveolar lavage evaluated after the LPS stimulus indicated reduced number of total cells in all compartments studied and different kinetics of migration in malnourished animals. The in vitro migration assay showed reduced capacity of migration after the LPS stimulus in malnourished animals $\left(45.7 \pm 17.2 \times 10^{4}\right.$ cells $\left./ \mathrm{mL}\right)$ compared to control $\left(69.6 \pm 7.1 \times 10^{4} \mathrm{cells} / \mathrm{mL}, \mathrm{P} \leq 0.05\right)$, but there was no difference in CD11a/CD18 expression on the surface of blood leukocytes. In addition, the production of IL-1 $\beta$ in vivo after the LPS stimulus $\left(180.7 \mathrm{pg} \cdot \mathrm{h}^{-1} \cdot \mathrm{mL}^{-1}\right)$, and in vitro by bone marrow and spleen cells $(41.6 \pm 15.0 \mathrm{and} 8.3 \pm 4.0 \mathrm{pg} /$ $\mathrm{mL}$ ) was significantly lower in malnourished animals compared to control $\left(591.1 \mathrm{pg} \cdot \mathrm{h}^{-1} \cdot \mathrm{mL}^{-1}, 67.0 \pm 23.0\right.$ and $17.5 \pm 8.0 \mathrm{pg} /$ $\mathrm{mL}$, respectively, $\mathrm{P} \leq 0.05$ ). The reduced expression of $\mathrm{IL}-1 \beta$, together with the lower number of leukocytes in the central and peripheral compartments, different leukocyte kinetics, and reduced leukocyte migration capacity are factors that interfere with the capacity to mount an adequate immune response, being partly responsible for the immunodeficiency observed in PEM.
\end{abstract}

Key words: Blood; Bone marrow; Spleen; Interleukin-1ß; Lipopolysaccharide; Malnutrition

\section{Introduction}

Protein energy malnutrition (PEM) is the most frequent type of malnutrition affecting millions of people worldwide, especially children, underweight newborn infants, the elderly, individuals with eating disorders such as nervous anorexia and bulimia, patients with neoplasias or chronic diseases, patients under chemotherapy or hospitalized patients of advanced age ( $\geq 60$ years), and individuals who undergo radical diets (1-3).

PEM-mediated impairment of the immune system results in increased morbidity and mortality due to infectious complications (1,2). PEM modifies physiological responses and may induce cellular lesions, and the extent and timing of damage differs depending on the tissue. Tissues with a high protein turnover are affected before those with a low protein turnover $(2,4)$.
The elevated and constant protein demand of hematopoietic tissue leads to a condition in which both qualitative and quantitative alterations may be found when PEM occurs. PEM modifies both the adaptive and innate immune response of organisms to infectious agents, such as a reduced production of blood cells, thereby leading to bone marrow hypoplasia and the induction of structural alterations in bone marrow (4-8).

Mobilization of inflammatory cells from the circulation into tissues is mediated by factors with local and systemic effects. In response to an inflammatory stimulus, monocytes and polymorphonuclear (PMN) leukocytes marginate and adhere to the endothelium and migrate into local inflammatory sites. Nutrition deficiencies increase the frequency and severity of infection, and this may be related to reduced

Correspondence: R.A. Fock, Departamento de Análises Clínicas e Toxicológicas, Faculdade de Ciências Farmacêuticas, USP, Av. Prof. Lineu Prestes, 580, Bloco 17, 05508-900 São Paulo, SP, Brasil. Fax: +55-11-3813-2197. E-mail: hemato@usp.br

Received May 19, 2011. Accepted September 4, 2012. Available online September 21, 2012. Published December $17,2012$. 
PMN leukocyte migration. CD11a/CD18 are molecules expressed in these cells and are involved in leukocyte migration capacity (9-11).

Mono/macrophages and PMN leukocytes are important phagocytic cells, and activation of these cells leads to the secretion of a number of pro-inflammatory cytokines such as interleukin 1 (IL-1), a potent immune and inflammatory mediator. Inflammatory cytokines can also be produced by cells involved in natural immunity after exposure to many pathogenic microorganisms and their products. A number of microbial products, including bacterial lipopolysaccharide (LPS), induce the synthesis of pro-inflammatory cytokines. The expression of IL-1 $\beta$ and other pro-inflammatory cytokines, such as IL-6 and tumor necrosis factor-alpha (TNF- $\alpha$ ), are an important mechanism of host defense against infection (12-15).

It is known that malnourished animals present severe hypoplasia of lympho-hemopoietic organs and functional alterations in leukocytes $(7,8,14,16)$. Thus, the objective of the present study was to evaluate the influence of PEM on the hematopoietic response after an LPS stimulus, as well as on the production of IL-1 $\beta$ and on the capacity of leukocyte migration.

\section{Material and Methods}

\section{Diets}

The murine diets were prepared in our laboratories. Mineral and vitamin mixtures were prepared according to the recommendations of the American Institute of Nutrition (AIN-93M) for adult mice (17), although the control diet contained $20 \%$ protein and the low-protein diet contained only $4 \%$. Both diets contained $100 \mathrm{~g} / \mathrm{kg}$ sucrose, $80 \mathrm{~g} / \mathrm{kg}$ corn oil, $10 \mathrm{~g} / \mathrm{kg}$ fiber, $2.5 \mathrm{~g} / \mathrm{kg}$ choline bitartrate, $1.5 \mathrm{~g} / \mathrm{kg}$ L-methionine, $40 \mathrm{~g} / \mathrm{kg}$ mineral mixture, and $10 \mathrm{~g} / \mathrm{kg}$ vitamin mixture. The control diet contained $200 \mathrm{~g} / \mathrm{kg}$ casein and $556 \mathrm{~g} / \mathrm{kg}$ cornstarch while the low-protein diet contained $40 \mathrm{~g} / \mathrm{kg}$ casein and $716 \mathrm{~g} / \mathrm{kg}$ cornstarch. The two diets were isocaloric and provided $1716.3 \mathrm{~kJ} / 100 \mathrm{~g}$. Final protein content was confirmed using the standard micro-Kjeldahl method (18).

\section{Animals}

Outbred male Swiss mice 2 to 3 months of age were obtained from the animal facilities of Faculdade de Ciências Farmacêuticas, Universidade de São Paulo. The animals were placed in individual "metabolic cages" and maintained under a regular 12-h light/dark cycle at a temperature of 22$25^{\circ} \mathrm{C}$ and with relative humidity of $55 \pm 10 \%$, receiving the control diet for 21 days until they stabilized their body weight. After this period of adaptation, the animals were divided into two groups: control $(\mathrm{N}=30)$ and malnourished $(\mathrm{N}=$ 30), receiving the control and the low-protein diet ad libitum, respectively. Their body weight and food consumption were monitored every $48 \mathrm{~h}$. Mice were subjected to experimental assays after 14 days of eating their respective diets, by which time the malnourished group had lost about $20 \%$ of their original body weight $(13,14)$. A nutritional evaluation was performed by measuring body weight, diet consumption and protein, albumin and pre-albumin concentrations in blood serum. The body weight variation was calculated considering the initial (after the adaptation period) and final (day of sacrifice) weight of the animals in both groups, and the results are reported as means $\pm S D$. The study was approved by the Ethics Committee of Faculdade de Ciências Farmacêuticas, Universidade de São Paulo.

\section{Endotoxemia by LPS}

Mice from control and malnourished groups were subjected to experimental endotoxemia after 14 days of eating their respective diets. Animals from both groups were intravenously inoculated via the caudal vein with $100 \mu \mathrm{L}$ LPS (Escherichia coli 055B5, Sigma, USA) at a concentration of $12.5 \mu \mathrm{g} / \mathrm{mL}$ diluted in a pyrogen-free aqueous solution of $0.9 \% \mathrm{NaCl}$. After the LPS stimulus, mice were anesthetized with $10 \mathrm{mg} / \mathrm{kg}$ xylazine chloral hydrate (Rompum ${ }^{\circledR}$, Bayer, Brazil) and $100 \mathrm{mg} / \mathrm{kg}$ ketamine chloral hydrate (Ketamina ${ }^{\circledR}$, Farex, Brazil), and were sacrificed at different times $(2,6$, $12,24 \mathrm{~h}$ ). At each time of sacrifice, serum was collected to determine IL-1 $\beta$ production and hemogram, myelogram, splenogram, and bronchoalveolar lavage cell count were performed.

\section{Hemogram, myelogram, splenogram, and bronchoalveolar lavage cell count}

After the LPS stimulus, mice were anesthetized and sacrificed and whole blood samples were collected concomitantly with bone marrow, spleen and bronchoalveolar cells. The same samples were collected from animals that had not received the LPS stimulus.

Blood samples were collected by cardiac puncture into tubes without or with EDTA as an anticoagulant (Sigma). Samples collected with EDTA were used to perform the hemogram and in samples without EDTA the serum was separated by centrifugation (1000 $\mathrm{g}$ for $10 \mathrm{~min}$ ) and used for total serum protein, albumin and pre-albumin determinations as well as IL-1 $\beta$ quantification.

Bone marrow cells were obtained by flushing the femoral cavity with $2 \mathrm{~mL}$ McCoy's 5A medium (Sigma) and spleen cells were obtained by gentle dissociation using needles and tweezers in $5 \mathrm{~mL}$ McCoy's 5A medium with EDTA (1 mg/ $\mathrm{mL})$. Bronchoalveolar lavage cells were obtained by trachea cannulation with polyethylene tubing and lung flushing with $5 \mathrm{~mL}$ McCoy's 5A medium. The recovered bone marrow, spleen and bronchoalveolar cells were centrifuged (170 g for $10 \mathrm{~min}$ at $20^{\circ} \mathrm{C}$ ), and the resulting cell pellets were resuspended in $1 \mathrm{~mL}$ McCoy's 5A medium for cell counting.

Hemoglobin concentration and hematocrit were determined by standard methods (19). Hemogram, myelogram, splenogram, and bronchoalveolar cell count were performed 
by counting leukocytes in a Neubauer chamber (Herka, Germany) by standard methods (19) and differential leukocyte counts were performed on smears stained with standard May-Grünwald-Giemsa solutions (Sigma).

\section{Measurement of CD11a/CD18 expression on circulating blood cells}

Total blood cells from control and malnourished animals without the LPS stimulus were collected by cardiac puncture as described above and used to quantify CD11a/ CD18 expression. Flow cytometry was used to determine the percent fraction of blood cells from control and malnourished animals that were positively labeled with fluorescein isothyocyanate (FITC)-conjugated rat anti-mouse CD11a (clone: 2D7 Cat. No. 553120, Becton Dickinson, USA) and FITC-conjugated rat anti-mouse CD18 (clone: M18/2 Cat. No. 11-0181, eBioscience, USA). The isotype control was FITC-conjugated rat immunoglobulin $\lg _{2 a} \mathrm{~K}$. The samples and negative chain controls were incubated with $1 \mu \mathrm{g}$ monoclonal antibody per $10^{6} \mathrm{cells} / \mathrm{mL}$, incubated for $20 \mathrm{~min}$ at $25^{\circ} \mathrm{C}$, and protected from light. After this period, the erythrocytes were lysed by adding $2 \mathrm{~mL} 10 \%$ lysing solution (Lysing Solution ${ }^{\circledR}$, Becton Dickinson) and were incubated again and protected from light for $15 \mathrm{~min}$. Next, the tubes were centrifuged at $400 \mathrm{~g}$ for $10 \mathrm{~min}$, the supernatant was discarded, and the cell sediment was washed twice with PBS containing $0.1 \%$ azide. The sediment was re-suspended in $500 \mu \mathrm{L}$ phosphate-buffered saline (PBS, Gibco ${ }^{\circledR}$ Invitrogen Cell Culture, USA), and cells were analyzed with a flow cytometer (FacsCalibur, Becton Dickinson). Fluorescence measurements were obtained with at least $1 \times 10^{4}$ cells. Data were analyzed using the Cell Quest ${ }^{\circledR}$ software package. The results are reported as a percentage of the gated population.

\section{In vitro chemotaxis assay}

Bone marrow cells were obtained by flushing the femoral cavity with $2 \mathrm{~mL}$ McCoy's 5A medium (Sigma) and PMN cells from control and malnourished animals were recovered from a density gradient consisting of Histopaque 1077 layered on top of Histopaque 1119 according to manufacturer instructions (Sigma). PMN cells from bone marrow were plated ( $1 \times 10^{6} /$ well in McCoy's $5 \mathrm{~A}$ medium, $01 \%$ BSA) in transwell inserts (precoated with 10\% fetal bovine serum) containing 8- $\mu$ m pores (Nunc, Denmark). LPS at a concentration of $1.25 \mu \mathrm{g}$ was added or not to the lower chamber and the plates were incubated at $37^{\circ} \mathrm{C}$ in a humidified atmosphere of $5 \% \mathrm{CO}_{2}$. PMN chemotaxis assays were performed for $2 \mathrm{~h}$. The migrating cells were then stained with standard May-Grünwald-Giemsa solutions (Sigma) prior to counting.

\section{Evaluation of circulating IL- $1 \beta$ levels after the LPS stimulus}

The IL-1 $\beta$ present in the serum of animals without the
LPS stimulus or after 2, 6, 12, and $24 \mathrm{~h}$ of LPS stimulus was quantified by ELISA using commercially available reagents (Quantikine ${ }^{\circledR}$ M murine, R\&D Systems, USA) according to the procedures recommended by the manufacturer. The samples were processed in duplicate.

\section{Bone marrow, spleen cell culture and IL-1 $\beta$ determination}

Cell viability was evaluated by the $0.1 \%$ Trypan blue exclusion test and, on average, $98 \%$ viability was obtained. The total bone marrow and spleen cells were cultured on 24-well, round-bottomed microtiter culture plates with $1 \mathrm{~mL}$ McCoy's 5A medium and $1.25 \mu \mathrm{g}$ LPS at a final concentration of $1 \times 10^{6}$ cells $/ \mathrm{mL}$. The cells were then incubated at $37^{\circ} \mathrm{C}$ in a humidified atmosphere of $5 \% \mathrm{CO}_{2}$ for $24 \mathrm{~h}$, and the supernatants were collected for cytokine determination. The entire procedure was executed under aseptic conditions, and all the materials used were previously sterilized and pyrogen-free. Cytokines were quantitated by ELISA using commercially available reagents (Quantikine ${ }^{\circledR}$ M murine, R\&D Systems) and following the procedures recommended by the manufacturer.

\section{Statistical analysis}

The dependent variables were normally distributed. Data were compared by the Student $t$-test and ANOVA using the statistics computer software GraphPad Prism ${ }^{\circledR}$. All data are reported as means \pm SD. The probability accepted as indicative of statistically significant differences was $P \leq 0.05$.

\section{Results}

\section{Protein consumption, body weight and serum protein, albumin and pre-albumin}

Mice maintained on the low-protein diet reduced their food consumption (control group $=6.8 \pm 0.51 \mathrm{~g} \cdot$ day $^{-1}$. animal $^{-1}$; malnourished group $=5.1 \pm 0.75 \mathrm{~g} \cdot$ day $^{-1} \cdot$ animal $^{-1}, \mathrm{~N}=30$ for each group, $\mathrm{P} \leq 0.05$ ), and their protein consumption (control group $=1.32 \pm 0.27 \mathrm{~g} \cdot$ day $^{-1} \cdot$ animal $^{-1} ;$ malnourished group $=0.21 \pm 0.09 \mathrm{~g} \cdot$ day $^{-1}$. animal ${ }^{-1}, \mathrm{~N}=30$ for each group, $\mathrm{P} \leq$ $0.05)$, resulting in a loss of $19 \%$ of their initial weight.

The serum proteins had decreased concentrations in mice maintained on the low-protein diet (control group = $7.4 \pm 0.96 \mathrm{~g} / \mathrm{dL} ;$ malnourished group $=4.9 \pm 0.77 \mathrm{~g} / \mathrm{dL}, \mathrm{N}$ $=30$ for each group, $\mathrm{P} \leq 0.05$ ), as also did albumin (control group $=4.5 \pm 0.6 \mathrm{~g} / \mathrm{dL}$; malnourished group $=3.2 \pm 0.4 \mathrm{~g} / \mathrm{dL}$, $\mathrm{N}=30$ for each group, $\mathrm{P} \leq 0.05$ ) and pre-albumin (control group $=10.8 \pm 1.2 \mathrm{mg} / \mathrm{dL} ;$ malnourished group $=2.9 \pm 1.9 /$ $\mathrm{mg} / \mathrm{dL}, \mathrm{N}=12$ for each group, $\mathrm{P} \leq 0.05$ ).

\section{Blood}

The malnourished animals had a decreased number of leukocytes as well as granulocytes, lymphocytes and monocytes (Table 1). No significant morphological differences 
were detected in these cells. The administration of LPS did not change the decreased number of leukocytes observed in malnourished animals. The LPS stimulus reduced the number of leukocytes in the control group $(P \leq 0.05)$ after 2 $h$, but an increase of the neutrophilic lineage was observed in the control group $24 \mathrm{~h}$ after the LPS stimulus.

\section{Cellularity of bone marrow and spleen}

Animals in the malnourished group had bone marrow and splenic hypoplasia (Tables 2 and 3 ) with a pronounced reduction in the myeloid compartment. The basal number of blast cells was significantly reduced in malnourished animals. After the LPS stimulus, we observed a distinct difference in the response of malnourished and control animals with a different neutrophilic kinetic of maturation and mobilization, showing an increase in neutrophilic cells in control animals after $24 \mathrm{~h}$ of the LPS stimulus.

\section{Bronchoalveolar lavage cell count}

As shown in Table 4, malnourished animals had fewer cells in the bronchoalveolar lavage than control animals. After the LPS stimulus, animals showed an increase in cell counts in the bronchoalveolar lavage, but this increase was higher in control than malnourished animals. In the control group, we observed an increase in neutrophils $2 \mathrm{~h}$ after the LPS stimulus, whereas in the malnourished group, this increase appeared after $6 \mathrm{~h}$ and with less intensity than in the control animals. In the control group, we observed an increase in macrophages $24 \mathrm{~h}$ after the LPS stimulus, and this response was not observed in malnourished animals.

\section{Blood cell CD11a/CD18 expression}

The CD11a/CD18 expression on blood cells (Figure 1) did not differ significantly between the control and malnourished groups, but tended to be lower in malnourished

Table 1. Blood counts of the number of total leukocytes, polymorphonuclear neutrophils, eosinophils, lymphocytes, and monocytes in control and malnourished mice stimulated or not with lipopolysaccharide.

\begin{tabular}{|c|c|c|c|c|c|c|c|c|c|c|}
\hline & \multicolumn{2}{|c|}{ Without LPS } & \multicolumn{2}{|c|}{ LPS $2 \mathrm{~h}$} & \multicolumn{2}{|c|}{ LPS $6 \mathrm{~h}$} & \multicolumn{2}{|c|}{ LPS $12 \mathrm{~h}$} & \multicolumn{2}{|c|}{ LPS $24 \mathrm{~h}$} \\
\hline & $\mathrm{CON}$ & M & CON & M & $\mathrm{CON}$ & M & CON & M & CON & M \\
\hline Leukocytes $\left(\mathrm{mm}^{3}\right)$ & $3401 \pm 91^{a, b}$ & $1450 \pm 56^{*}$ & $2720 \pm 53^{b, c}$ & $1109 \pm 74^{*}$ & $2937 \pm 71^{a}$ & $1008 \pm 96^{*}$ & $3120 \pm 118^{c}$ & $1052 \pm 88^{*}$ & $3710 \pm 103^{a, b}$ & $1048 \pm 71^{*}$ \\
\hline $\begin{array}{l}\text { Neutrophils: } \\
\text { band cells }\left(\mathrm{mm}^{3}\right)\end{array}$ & $18.1 \pm 1.0^{a, b}$ & $3.2 \pm 0.8^{*}$ & $2.1 \pm 0.5^{a, c}$ & $1.3 \pm 0.7$ & $1.8 \pm 0.5^{b, d}$ & $1.2 \pm 0.8$ & $16.1 \pm 1.4^{\mathrm{c}, \mathrm{d}}$ & $3.4 \pm 1.1^{*}$ & $24.1 \pm 1.0^{\mathrm{a}, \mathrm{b}, \mathrm{c}}$ & $3.9 \pm 1.2$ \\
\hline $\begin{array}{l}\text { Neutrophils: } \\
\text { segmented }\left(\mathrm{mm}^{3}\right)\end{array}$ & $681 \pm 35^{a}$ & $208 \pm 35^{*}$ & $580 \pm 38^{b}$ & $164 \pm 38^{*}$ & $648 \pm 61^{c}$ & $172 \pm 23^{*}$ & $738.5 \pm 51^{b}$ & $184.3 \pm 22^{*}$ & $991 \pm 85^{a, b, c}$ & $181 \pm 53^{*}$ \\
\hline Eosinophils $\left(\mathrm{mm}^{3}\right)$ & $11.0 \pm 3.1^{a, b, c, d}$ & $1.8 \pm 1.4^{*}$ & $0^{a}$ & 0 & $0^{\mathrm{b}}$ & 0 & $0^{c}$ & 0 & $0^{d}$ & 0 \\
\hline $\begin{array}{l}\text { Lymphocytes } \\
\left(\mathrm{mm}^{3}\right)\end{array}$ & $2559 \pm 99^{a, b}$ & $1250 \pm 87^{\star, c, d}$ & $2138 \pm 87^{a}$ & $910 \pm 111^{*}$ & $2148 \pm 91^{b}$ & $805 \pm 93^{\star}, \mathrm{C}$ & $2320 \pm 79$ & $808 \pm 121^{*}$ & $2401 \pm 93$ & $804 \pm 87^{*, d}$ \\
\hline Monocytes $\left(\mathrm{mm}^{3}\right)$ & $79.2 \pm 8.1^{a, b, c, d}$ & $11 \pm 2.7^{\star, e, f, g, h}$ & $19.9 \pm 1.0^{\mathrm{a}}$ & $2.1 \pm 1.38^{\star, \mathrm{e}}$ & $11.4 \pm 1.1^{b}$ & $5.1 \pm 0.4^{\star, f}$ & $18.7 \pm 2.1^{\mathrm{c}}$ & $3.0 \pm 0.4^{\star}, \mathrm{g}$ & $26 \pm 4.1^{d}$ & $2.7 \pm 0.9^{*, h}$ \\
\hline
\end{tabular}

Data are reported as means \pm SD number of leukocytes and of different types of white blood cells in the blood of control (CON) and malnourished (M) mice inoculated intravenously with $1.25 \mathrm{\mu g}$ lipopolysaccharide (LPS). Blood from 6 mice per group was analyzed at each time point. ${ }^{*} \mathrm{P} \leq 0.05$ compared to $\mathrm{CON}$ ( $t$-test). The same superscript letter indicates a significant difference between groups $(\mathrm{P}$ $\leq 0.05$; one-way ANOVA).

Table 2. Number of total and differential counts of bone marrow cells from control and malnourished mice stimulated or not with lipopolysaccharide.

\begin{tabular}{|c|c|c|c|c|c|c|c|c|c|c|}
\hline \multirow[t]{2}{*}{$\left(\times 10^{6} / \mathrm{mL}\right)$} & \multicolumn{2}{|c|}{ Without LPS } & \multicolumn{2}{|c|}{ LPS $2 \mathrm{~h}$} & \multicolumn{2}{|c|}{ LPS $6 \mathrm{~h}$} & \multicolumn{2}{|c|}{ LPS $12 \mathrm{~h}$} & \multicolumn{2}{|c|}{ LPS $24 \mathrm{~h}$} \\
\hline & $\mathrm{CON}$ & M & CON & M & CON & M & $\mathrm{CON}$ & M & CON & M \\
\hline $\begin{array}{l}\text { Total bone } \\
\text { marrow cells }\end{array}$ & $7.70 \pm 0.6^{a}$ & $4.91 \pm 0.6^{*}$ & $7.05 \pm 0.8$ & $4.08 \pm 0.4^{*}$ & $6.89 \pm 1.1$ & $4.29 \pm 0.9$ & $6.41 \pm 0.6$ & $4.28 \pm 0.9$ & $6.12 \pm 0.7^{a}$ & $4.14 \pm 0.5$ \\
\hline Blast cells & $0.5 \pm 0.09$ & $0.21 \pm 0.02^{*}$ & $0.39 \pm 0.04$ & $0.23 \pm 0.05$ & $0.30 \pm 0.03$ & $0.20 \pm 0.04$ & $0.33 \pm 0.05$ & $0.19 \pm 0.05$ & $0.37 \pm 0.07$ & $0.24 \pm 0.05^{*}$ \\
\hline $\begin{array}{l}\text { Neutrophils: } \\
\text { promyelocytic and } \\
\text { myelocytic cells }\end{array}$ & $0.51 \pm 0.10$ & $0.36 \pm 0.03^{*}$ & $0.41 \pm 0.05$ & $0.24 \pm 0.06^{*}$ & $0.39 \pm 0.03$ & $0.36 \pm 0.04$ & $0.31 \pm 0.03$ & $0.34 \pm 0.03$ & $0.38 \pm 0.10$ & $0.33 \pm 0.7$ \\
\hline $\begin{array}{l}\text { Neutrophils: band } \\
\text { cells }\end{array}$ & $1.94 \pm 0.08^{a, b}$ & $1.09 \pm 0.04^{*}$ & $2.21 \pm 0.12^{c, d}$ & $0.47 \pm 0.03^{*}$ & $1.71 \pm 0.11$ & $0.46 \pm 0.03^{*}$ & $1.64 \pm 0.09^{a, c}$ & $0.48 \pm 0.05^{*}$ & $1.56 \pm 0.11^{b, d}$ & $0.47 \pm 0.06^{*}$ \\
\hline $\begin{array}{l}\text { Neutrophils: } \\
\text { segmented }\end{array}$ & $1.61 \pm 0.12^{a, b, c, d}$ & $1.21 \pm 0.09^{*}$ & $1.20 \pm 0.11^{*}$ & $1.28 \pm 0.14$ & $1.36 \pm 0.13^{b}$ & $1.29 \pm 0.11$ & $1.39 \pm 0.12^{c}$ & $1.41 \pm 0.14$ & $1.98 \pm 0.07 a, b, c, d$ & $1.31 \pm 0.05^{*}$ \\
\hline Eosinophils & $0.15 \pm 0.08$ & $0.07 \pm 0.03$ & $0.09 \pm 0.04$ & $0.05 \pm 0.02$ & $0.04 \pm 0.02$ & $0.04 \pm 0.01$ & $0.05 \pm 0.01$ & $0.07 \pm 0.01$ & $0.03 \pm 0.01$ & $0.03 \pm 0.01$ \\
\hline Lymphocytes & $1.41 \pm 0.12$ & $1.52 \pm 0.12$ & $1.40 \pm 0.21$ & $1.62 \pm 0.19$ & $1.53 \pm 0.15$ & $1.63 \pm 0.18$ & $1.39 \pm 0.11$ & $1.57 \pm 0.13$ & $1.35 \pm 0.14$ & $1.54 \pm 0.7$ \\
\hline Macrophase & $0.08 \pm 0.02$ & $0.03 \pm 0.01$ & $0.04 \pm 0.01$ & $0.02 \pm 0.01$ & $0.02 \pm 0.01$ & $0.03 \pm 0.01$ & $0.03 \pm 0.02$ & $0.02 \pm 0.02$ & $0.05 \pm 0.03$ & $0.02 \pm 0.7$ \\
\hline
\end{tabular}

Data are reported as means \pm SD number of cells present in the bone marrow of control (CON) and malnourished (M) mice inoculated intravenously with $1.25 \mu \mathrm{g}$ lipopolysaccharide (LPS). Bone marrow from 6 mice per group was analyzed at each time point. ${ }^{*} \mathrm{P} \leq 0.05$ compared to CON at each time point studied ( $t$-test). The same supercript letter indicates a significant difference between groups $(P$ $\leq 0.05$; one-way ANOVA). 
Table 3. Total and differential counts of spleen cells from control and malnourished mice stimulated or not with lipopolysaccharide.

\begin{tabular}{|c|c|c|c|c|c|c|c|c|c|c|}
\hline \multirow[t]{2}{*}{$\left(\times 10^{6} / \mathrm{mL}\right)$} & \multicolumn{2}{|c|}{ Without LPS } & \multicolumn{2}{|c|}{ LPS $2 \mathrm{~h}$} & \multicolumn{2}{|c|}{ LPS $6 \mathrm{~h}$} & \multicolumn{2}{|c|}{ LPS $12 \mathrm{~h}$} & \multicolumn{2}{|c|}{ LPS $24 \mathrm{~h}$} \\
\hline & CON & M & CON & M & CON & $M$ & CON & M & CON & M \\
\hline Total spleen cells & $8.11 \pm 0.41$ & $4.71 \pm 0.39^{\star}$ & $7.40 \pm 0.92$ & $4.43 \pm 1.1^{*}$ & $7.05 \pm 0.93$ & $4.03 \pm 0.71^{*}$ & $7.08 \pm 0.83$ & $4.11 \pm 0.75^{*}$ & $7.21 \pm 0.71$ & $4.13 \pm 0.63^{*}$ \\
\hline Blast cells & $0.41 \pm 0.09$ & $0.29 \pm 0.01^{*}$ & $0.39 \pm 0.11$ & $0.29 \pm 0.06$ & $0.28 \pm 0.09$ & $0.14 \pm 0.07$ & $0.29 \pm 0.09$ & $0.13 \pm 0.06^{*}$ & $0.30 \pm 0.06$ & $0.13 \pm 0.03^{*}$ \\
\hline $\begin{array}{l}\text { Neutrophils: } \\
\text { promyelocytic and } \\
\text { myelocytic cells }\end{array}$ & $0.52 \pm 0.07^{a}$ & $0.20 \pm 0.04^{*}$ & $0.48 \pm 0.17$ & $0.17 \pm 0.21$ & $0.32 \pm 0.11$ & $0.03 \pm 0.03^{*}$ & $0.30 \pm 0.19$ & $0.01 \pm 0.05^{*}$ & $0.26 \pm 0.07^{\mathrm{a}}$ & $0.01 \pm 0.01^{*}$ \\
\hline $\begin{array}{l}\text { Neutrophils: } \\
\text { band cells }\end{array}$ & $0.22 \pm 0.03^{a}$ & $0.19 \pm 0.05$ & $0.24 \pm 0.02^{b}$ & $0.09 \pm 0.01^{*}$ & $0.12 \pm 0.03^{a, b, c}$ & $0.03 \pm 0.01^{*}$ & $0.28 \pm 0.04^{c}$ & $0.05 \pm 0.01^{*}$ & $0.19 \pm 0.08$ & $0.07 \pm 0.04^{*}$ \\
\hline Neutrophils: segmented & $0.48 \pm 0.06$ & $0.30 \pm 0.07^{\star}$ & $0.44 \pm 0.03$ & $0.19 \pm 0.12$ & $0.42 \pm 0.04$ & $0.16 \pm 0.05$ & $0.39 \pm 0.04^{a}$ & $0.19 \pm 0.06$ & $0.57 \pm 0.05^{a}$ & $0.20 \pm 0.05^{*}$ \\
\hline Lymphocytes & $5.91 \pm 0.87$ & $3.60 \pm 0.71^{*}$ & $5.48 \pm 0.71$ & $3.71 \pm 0.88^{*}$ & $5.22 \pm 0.69$ & $3.88 \pm 0.78^{*}$ & $5.07 \pm 0.84$ & $3.78 \pm 0.88^{*}$ & $5.21 \pm 0.06$ & $3.80 \pm 0.06^{*}$ \\
\hline Macrophages & $0.09 \pm 0.05$ & $0.02 \pm 0.01$ & $0.09 \pm 0.06$ & $0.01 \pm 0.01$ & $0.09 \pm 0.06$ & $0.02 \pm 0.02$ & $0.14 \pm 0.06$ & $0.04 \pm 0.04$ & $0.09 \pm 0.06$ & $0.03 \pm 0.02$ \\
\hline
\end{tabular}

Data are reported as means \pm SD numbers of cells present in the spleen of control (CON) and malnourished (M) mice inoculated intravenously with $1.25 \mu \mathrm{g}$ lipopolysaccharide (LPS). Spleen cells from 6 mice per group were analyzed at each time point. ${ }^{*} \mathrm{P} \leq 0.05$ compared to CON at each time point studied ( $t$-test). The same superscript letter indicates a significant difference between groups ( $\leq \leq 0.05$; one-way ANOVA).

Table 4. Number of total and differential counts of bronchoalveolar lavage cells from control and malnourished mice stimulated or not with lipopolysaccharide.

\begin{tabular}{|c|c|c|c|c|c|c|c|c|c|c|}
\hline \multirow[t]{2}{*}{$\left(\times 10^{4} / \mathrm{mL}\right)$} & \multicolumn{2}{|c|}{ Without LPS } & \multicolumn{2}{|c|}{ LPS $2 \mathrm{~h}$} & \multicolumn{2}{|c|}{ LPS $6 \mathrm{~h}$} & \multicolumn{2}{|c|}{ LPS $12 \mathrm{~h}$} & \multicolumn{2}{|c|}{ LPS $24 \mathrm{~h}$} \\
\hline & CON & M & $\mathrm{CON}$ & M & CON & M & $\mathrm{CON}$ & $M$ & $\mathrm{CON}$ & M \\
\hline Total cells & $16.7 \pm 0.7^{a, b}$ & $9.9 \pm 0.9^{*} \mathrm{e}$ & $19.7 \pm 2.8^{c}$ & $12.1 \pm 2.1$ & $19.1 \pm 2.1^{d}$ & $18.1 \pm 2.3^{e, f}$ & $24.8 \pm 1.1^{a}$ & $12.1 \pm 1.2^{*}$ & $29.1 \pm 2.1^{b, c, d}$ & $10.6 \pm 0.9^{*, f}$ \\
\hline Neutrophils & $1.3 \pm 0.2^{a, b, c}$ & $1.0 \pm 0.2^{g}$ & $6.1 \pm 0.4 \mathrm{a}, \mathrm{d}$ & $1.7 \pm 0.2^{\star, h}$ & $7.2 \pm 0.3^{\mathrm{b}, \mathrm{e}}$ & $2.7 \pm 0.6^{\star}, \mathrm{g}, \mathrm{i}$ & $5.7 \pm 0.3^{c, f}$ & $1.4 \pm 0.1^{*}$ & $1.6 \pm 0.6^{\mathrm{d}, e, f}$ & $0.9 \pm 0.2^{h, i}$ \\
\hline Eosinophils & $0.33 \pm 0.09^{a}$ & $0.06 \pm 0.02^{*}$ & $0.09 \pm 0.02$ & $0.01 \pm 0.02$ & $0.08 \pm 0.04$ & $0.01 \pm 0.02$ & $0.12 \pm 0.02$ & $0.01 \pm 0.01$ & $0.01 \pm 0.01^{a}$ & $0.01 \pm 0.01$ \\
\hline Lymphocytes & $11.1 \pm 0.9$ & $8.0 \pm 0.5^{*}$ & $9.8 \pm 1.2^{\mathrm{a}}$ & $8.4 \pm 1.3$ & $9.1 \pm 1.1^{b}$ & $10.3 \pm 1.4$ & $10.7 \pm 0.7$ & $9.4 \pm 0.7^{*}$ & $14.2 \pm 0.9^{a, b}$ & $8.0 \pm 0.7^{*}$ \\
\hline Macrophages & $5.1 \pm 0.5^{a}$ & $1.1 \pm 0.3^{*}$ & $5.2 \pm 0.5^{b}$ & $0.9 \pm 0.1^{*}$ & $5.0 \pm 0.5^{c}$ & $1.9 \pm 0.6^{*}$ & $8.3 \pm 0.7^{d}$ & $1.5 \pm 0.2^{*}$ & $11.1 \pm 0.5 \mathrm{a}, \mathrm{b}, \mathrm{c}, \mathrm{d}$ & $1.8 \pm 0.5^{\star}$ \\
\hline
\end{tabular}

Data are reported as means \pm SD number of cells present in the bronchoalveolar lavage of control $(\mathrm{CON})$ and malnourished (M) mice inoculated intravenously with $1.25 \mu \mathrm{g}$ lipopolysaccharide (LPS). Bronchoalveolar lavage cells from 6 mice per group were analyzed at each time point. ${ }^{*} \mathrm{P} \leq 0.05$ compared to $\mathrm{CON}$ at each time point studied ( $t$-test). The same superscript letter indicates a significant difference between groups ( $\mathrm{P} \leq 0.05$; one-way ANOVA).

animals than in the control group.

\section{In vitro chemotaxis assay}

Control and malnourished groups showed the same migration capacity when PMN cells were incubated without LPS. However, PMN cells in a migration assay with LPS showed a reduced migration capacity in the malnourished group compared to control (Figure 2).

\section{IL-1 $\beta$ production}

Malnourished animals produced less IL-1 $\beta$ during the in vivo and in vitro tests. Figure $3 A$ shows the IL- $1 \beta$ production in the circulation after the LPS stimulus, and the analysis of the area under the curve showed that IL-1 $\beta$ production in malnourished animals was lower than in the control group (180.7 and $591.1 \mathrm{pg} \cdot \mathrm{h}^{-1} \cdot \mathrm{mL}^{-1}$, respectively). Peak IL-1 $\beta$ production started $2 \mathrm{~h}$ after the LPS stimulus in control animals, and this peak was delayed by $4 \mathrm{~h}$ in malnourished animals.

The IL-1 $\beta$ determinations made in the supernatants of cultured bone marrow and spleen cells (Figure 3B and C, respectively) were carried out with a 1.25- $\mu$ g LPS stimulus for $24 \mathrm{~h}$. The IL-1 $\beta$ concentrations were significantly lower $(P \leq 0.05)$ in cell cultures of malnourished mice compared to control.

\section{Discussion}

PEM impairs the host's immune system, thereby increasing susceptibility to infection (10). We have shown that PEM affects the central and peripheral hematological kinetic response after endotoxemia and impairs the migration capacity as wells the production of IL-1 $\beta$.

The control group received adequate protein in their diet, and the test group received a low-protein diet, had a markedly lower food intake and experienced about a $20 \%$ loss of body weight. As a result, even though the animals ingested a lower amount of food, the diet we prepared met the minimum nutrient requirements for adult mice (17). Because the animals in the malnourished group ingested the minimum daily amounts of nutrients required, we may conclude that the changes observed in our experimental 
model were mainly the result of the reduction in protein and energy intake compared to the control group.

Leukopenia and leukocytosis are situations that occur during malnutrition, especially in humans, when accompanied by infectious processes or chronic disease $(4,10,20,21)$, but there is evidence that in situations in which malnutrition is not accompanied by other diseases, leukopenia is always present $(20,22)$.

The reduced numbers of blood leukocytes exhibited by malnourished animals in this study were accompanied by bone marrow and spleen hypoplasia and, furthermore, the animals of the malnourished group that received LPS presented a hematological response that was both central and peripheral in nature and smaller than that which occurred in control animals. The granulocytic lineage showed a distinct behavior when both groups were analyzed. Malnourished animals had a lower number of granulocytic precursors in the central compartments (bone marrow and spleen) and decreased granulocyte production, kinetic maturation and impaired recruitment of leukocytes from the bone marrow pool to the circulation, with a suggestive delay in leukocyte mobilization when compared to control animals.

Endotoxins alter cell mobilization not only by releasing marginated granulocytes but also by modifying the influx into the maturation compartment $(23,24)$. We observed in this study that the response from cell production to cell
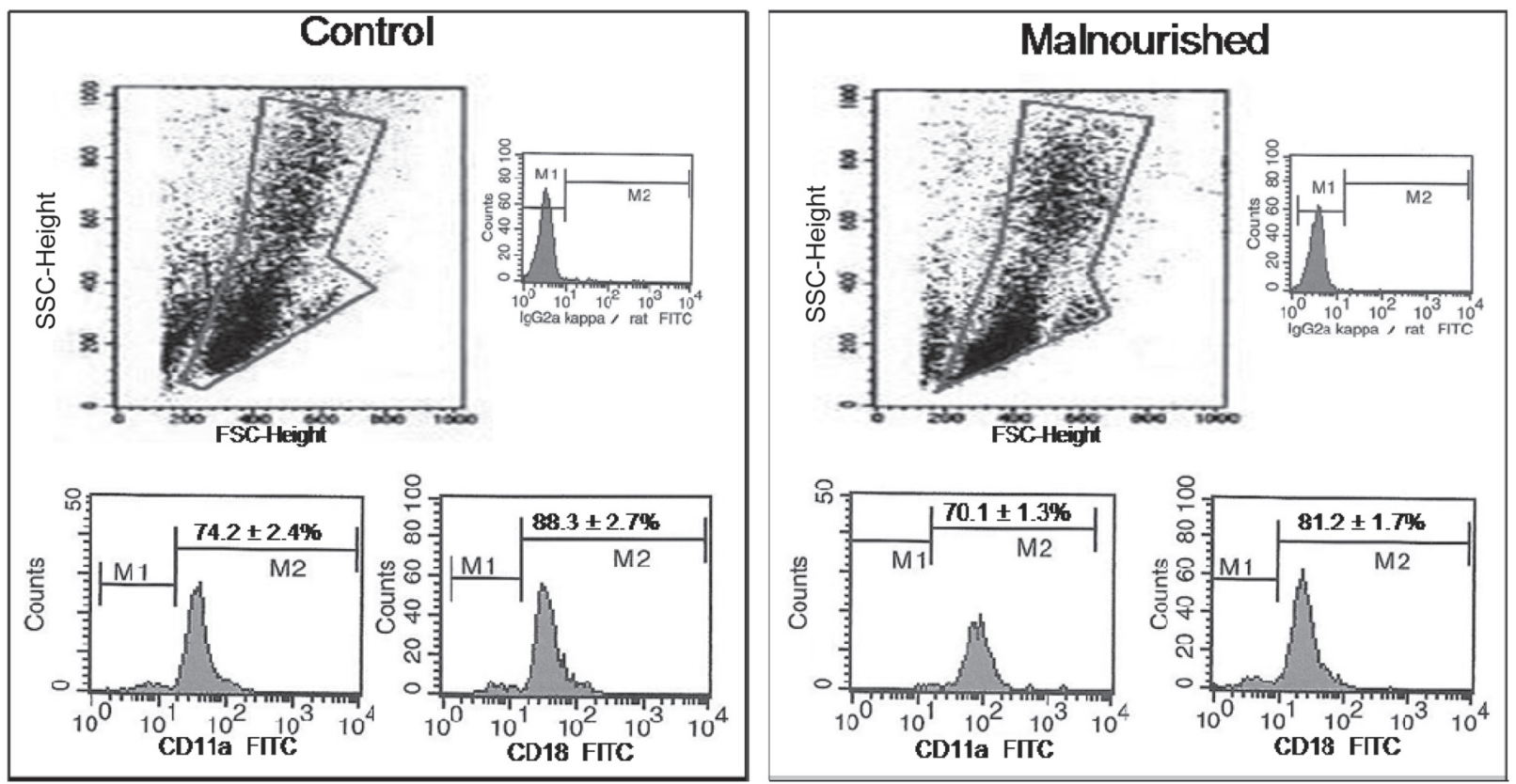

Figure 1. CD11a and CD18 expression on peripheral leukocytes obtained from control and malnourished mice. Data are reported as means \pm SD for 6 mice in each group. Data were obtained by blood flow cytometry; $10^{4}$ cells were acquired in a flow cytometer with a 488-nm argon laser (FacsCalibur, Becton Dickinson). The selection of gate R1 of the cell populations that were not marked with fluorochromes is indicated. Immunophenotyping analysis was carried out in gate R1 for CD11a and CD18. SSC = side angle scattered light; FSC = forward angle scattered light; FITC = fluorescein isothyocyanate.

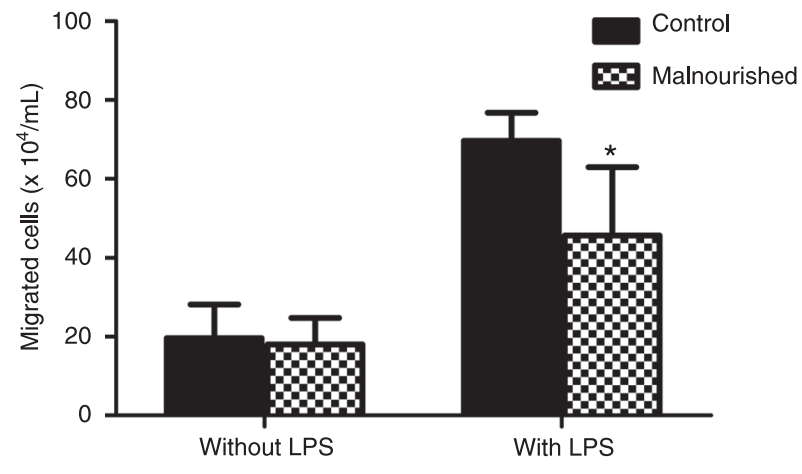

Figure 2. Migration of bone marrow polymorphonuclear cells from control and malnourished mice evaluated in an in vitro assay system incubated without or with $1.25 \mu \mathrm{g}$ lipopolysaccharide (LPS). Data are reported as means \pm SD for 6 mice in each group. ${ }^{*} \mathrm{P} \leq$ 0.05 compared to control ( $t$-test). 
mobilization was completely different between control and malnourished animals. Our study used a high concentration of LPS to induce high levels of cytokine production, and these levels correspond to those reported in Gram-negative sepsis in vivo (25).

We demonstrated that malnourished animals have a low ability to trigger leukocyte migration to the lung, which is an important target organ for leukocyte mobilization during sepsis and malnutrition is often cited as a risk factor for lung infections (26). Previous study of our group observed fewer neutrophils in the alveolar septa of malnourished animals and found that fewer cells accumulated in tissue by transmigration across post-capillary venules after endotoxemia. This showed that malnourished animals did not properly recruit leukocytes from the bone marrow to the circulation (27), a fact that may have resulted from a combination of adhesion and migratory defects in these animals.

Adhesion molecules such as CD11a and CD18 play important roles in cell recruitment (28). In the present study, dietary restriction did not significantly reduce the expres-
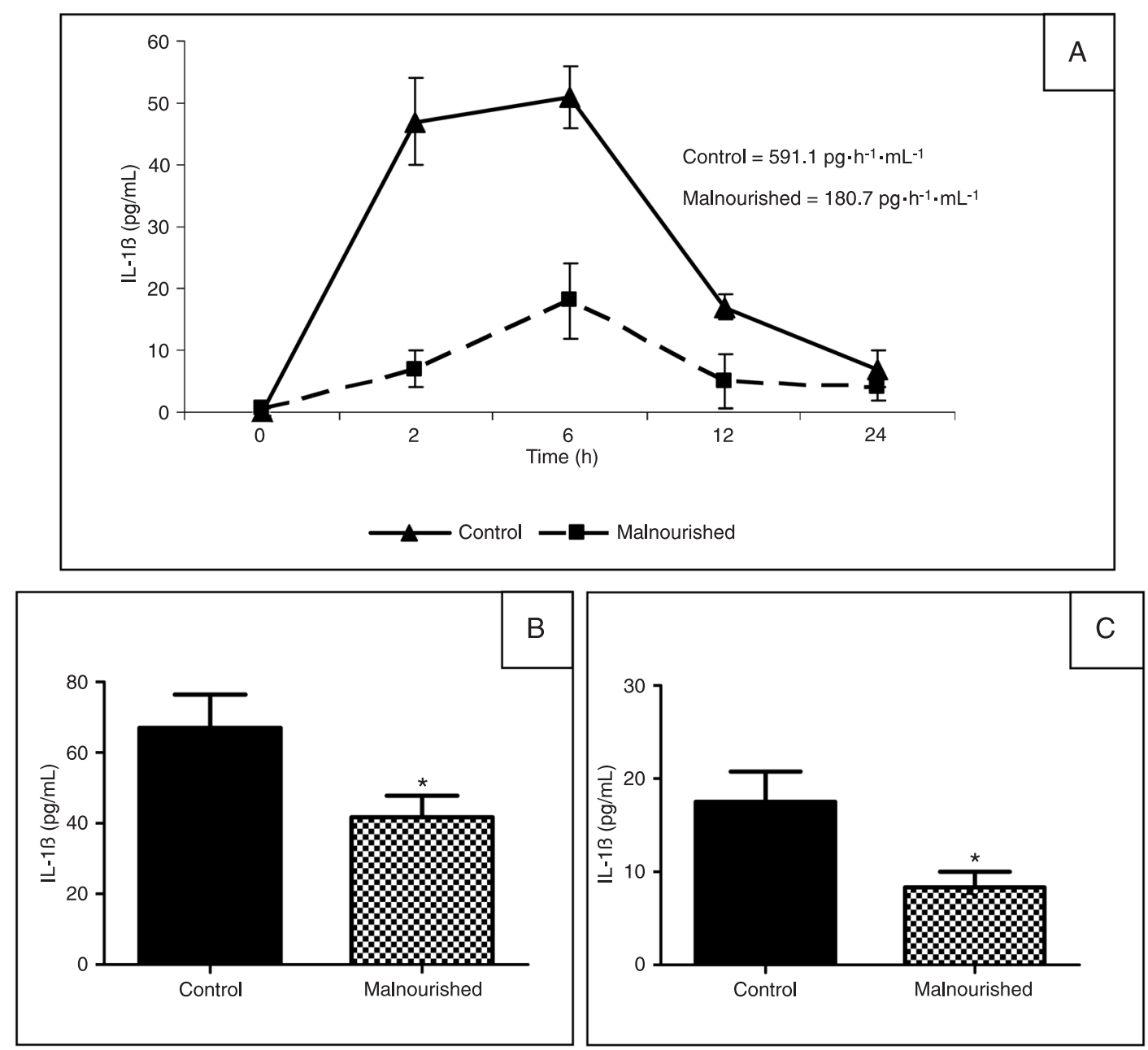

Figure 3. $A$, Kinetics of systemic interleukin-1 $\beta(\mathrm{IL}-1 \beta)$ production in control and malnourished mice inoculated intravenously with $1.25 \mu \mathrm{g}$ lipopolysaccharide (LPS). Data are reported as means \pm SD and the area under the curve of the production. Six mice per group were analyzed at each time point. Analysis of the area under the curve demonstrated that the concentration of IL-1 $\beta$ in mice from the malnourished group was significantly lower than in mice from the control group (180.7 and $591.1 \mathrm{pg} \cdot \mathrm{h}^{-1} \cdot \mathrm{mL}^{-1}$, respectively, $\mathrm{P} \leq 0.05$; $t$-test). $B$, Determination of bone marrow IL-1 $\beta$. Data are reported as means \pm SD IL-1 $\beta$ in the bone marrow supernatant of cells cultured with $1.25 \mu \mathrm{g}$ LPS for $24 \mathrm{~h}$ at a final concentration of $1 \times 10^{6} \mathrm{cells} / \mathrm{mL}$, from mice of the control $(\mathrm{N}=6)$ and malnourished $(\mathrm{N}=6)$ groups. ${ }^{*} \mathrm{P} \leq 0.05$ compared to control ( $t$-test). $C$, Spleen IL-1 $\beta$ determination. Data are reported as means \pm SD IL- $1 \beta$ in the spleen supernatant of cells cultured with $1.25 \mu \mathrm{g}$ LPS for $24 \mathrm{~h}$ at a final concentration of $1 \times 10^{6} \mathrm{cells} / \mathrm{mL}$, of mice from the control $(N=6)$ and malnourished $(N=6)$ groups. ${ }^{*} P \leq 0.05$ compared to control ( $t$-test). 
sion of these molecules, although malnourished animals showed a tendency to have lower CD11a/CD18 expression. However, we showed that PMN cells from malnourished animals had a reduced migration capacity in vitro when these cells were stimulated with LPS. The literature shows that animals subjected to protein malnutrition were unable to induce an acute inflammatory response against a specific antigen, with a dramatic reduction in leukocyte adhesion and down-regulation of the expression of endothelial intercellular adhesion molecule 1 (29).

Thus, the altered leukocyte response observed in malnourished animals is likely to be the result of different mechanisms. However, data regarding cell mobilization during malnutrition are also divergent (30). Leukocyte transmigration through the vessel wall and through tissue toward an inflammatory site is crucial in the development of the inflammatory response. Leukocyte migration through tissue is influenced by the tissue architecture and by the composition of the local extracellular matrix (31).

This reduction in the capacity to respond to an infectious stimulus may be partly due to alterations in the extracellular matrix observed in malnourished animals $(7,8)$. The alteration in the mobilization of inflammatory cells may be due to a smaller availability of these cells in the circulation and at hematopoietic sites and also to the hampering of chemotaxis and leukocyte migration, which results from changes in adhesion proteins such as fibronectin present on the cell surface as well as the decreased production of chemotactic cytokines such as IL-8 and a lower expression of selectins and integrins $(7,32)$. The production of hematopoietic cells, as well as the cell migration into and out of bone marrow, are critical for normal homeostasis of the circulating pool of leukocytes and lymphoid organs (33). In this context, our group has demonstrated that proteinenergy malnutrition alters the production of hematopoietic cells, showing that progenitor cells are stopped in the G0/ G1 phase of the cell cycle (6).

It is known that LPS has multiple and divergent effects on mono/macrophages and PMN cells, as it regulates cellular functions such as cell motility, and stimulates the synthesis of inflammatory mediators. LPS induction of IL-1 $\beta$ is rapid and transient, and the kinetics of IL- $1 \beta$ production can be physiologically related to the inflammatory response induced by this potent bacterial toxin. It should be emphasized that the systemic effects of this cytokine are quite different from their local effects, which are well tolerated by the organism as a whole. Pro-inflammatory cytokines such as IL-1 $\beta$ and TNF- $\alpha$ increase circulating neutrophils by releasing them from marginated pools $(32,34-37)$.

Our results showed that malnourished animals had distinct kinetics of IL-1 $\beta$ synthesis and a lower IL-1 $\beta$ concentration in the circulation after endotoxemia. The in vitro experiments confirmed these results, showing that malnourished animals do not have the same capacity to produce IL-1 $\beta$, and since the number of cells used for in vitro experiments were normalized in both groups, we can infer that the reduced production of IL-1 $\beta$ is probably an intrinsic problem and not a consequence of hypoplasia and a possible decrease of immune cells observed during malnutrition. Our group demonstrated that cells from malnourished animals have a lower capacity to activate the transcription factor NF-KB, which is involved in the transcription of pro-inflammatory genes including IL-1 $\beta$ (13), and this could explain the decreased IL-1 $\beta$ synthesis.

IL-1 $\beta$ interacts with different cell lineage receptors that can produce a local or systemic response and result in a different intensity of activation (35). Uncontrolled production of this inflammatory cytokine may lead to serious systemic complications such as microcirculatory dysfunction, tissue damage, and septic shock (36). In this context, our previous data (38) demonstrated that malnourished animals stimulated with LPS produce more IL-10 and this uncontrolled balance between pro-inflammatory and anti-inflammatory cytokines could explain, in part, what happens, leading us to infer that uncontrolled production of IL-1 $\beta$ with high levels of IL-10 leads to the immune deficiency common in malnutrition.

The impaired number of leukocytes migrating to the lungs with reduced neutrophil mobilization could be due to several mechanisms, such as rolling adhesion and impaired migration $(34,39)$; however, one of the mechanisms that might explain this impairment is reduced IL- $1 \beta$ levels, which would contribute to attenuated leukocytosis.

In light of the data obtained in the present study, we showed that malnourished animals exhibit a reduction in the parameters evaluated and do not respond with the same intensity or in the same manner as well-nourished animals.

\section{Acknowledgments}

Research supported by FAPESP.

\section{References}

1. Scrimshaw NS. INCAP studies of nutrition and infection. Food Nutr Bull 2010; 31: 54-67.

2. Keusch GT. The history of nutrition: malnutrition, infection and immunity. J Nutr 2003; 133: 336S-340S.

3. Waitzberg DL, Caiaffa WT, Correia MI. Hospital malnutrition: the Brazilian national survey (IBRANUTRI): a study of 4000 patients. Nutrition 2001; 17: 573-580.
4. Catchatourian R, Eckerling G, Fried W. Effect of short-term protein deprivation on hemopoietic functions of healthy volunteers. Blood 1980; 55: 625-628.

5. Fried W, Barone SJ, Anagnostou A. Effect of protein deprivation on hematopoietic stem cells and on peripheral blood counts. $J$ Lab Clin Med 1978; 92: 303-310.

6. Borelli P, Barros FE, Nakajima K, Blatt SL, Beutler B, Pereira J, 
et al. Protein-energy malnutrition halts hemopoietic progenitor cells in the G0/G1 cell cycle stage, thereby altering cell production rates. Braz J Med Biol Res 2009; 42: 523-530.

7. Xavier JG, Favero ME, Vinolo MA, Rogero MM, Dagli ML, Arana-Chavez VE, et al. Protein-energy malnutrition alters histological and ultrastructural characteristics of the bone marrow and decreases haematopoiesis in adult mice. Histol Histopathol 2007; 22: 651-660.

8. Vituri CL, Alvarez-Silva M, Trentin AG, Borelli P. Alterations in proteins of bone marrow extracellular matrix in undernourished mice. Braz J Med Biol Res 2000; 33: 889-895.

9. Keenan RA, Moldawer LL, Yang RD, Kawamura I, Blackburn GL, Bistrian BR. An altered response by peripheral leukocytes to synthesize or release leukocyte endogenous mediator in critically ill, protein-malnourished patients. J Lab Clin Med 1982; 100: 844-857.

10. Grimble RF. Interaction between nutrients, pro-inflammatory cytokines and inflammation. Clin Sci 1996; 91: 121-130.

11. Landgraf MA, Martinez LL, Rastelli VM, Franco MC, SotoSuazo M, Tostes RC, et al. Intrauterine undernutrition in rats interferes with leukocyte migration, decreasing adhesion molecule expression in leukocytes and endothelial cells. J Nutr 2005; 135: 1480-1485.

12. Dulger $H$, Arik $M$, Sekeroglu MR, Tarakcioglu $M$, Noyan $T$, Cesur Y, et al. Pro-inflammatory cytokines in Turkish children with protein-energy malnutrition. Mediators Inflamm 2002; 11: 363-365.

13. Fock RA, Rogero MM, Vinolo MA, Curi R, Borges MC, Borelli $P$. Effects of protein-energy malnutrition on NF-kappaB signalling in murine peritoneal macrophages. Inflammation 2010; 33: 101-109.

14. Fock RA, Vinolo MA, de Moura de Sa Rocha V, de Sa Rocha LC, Borelli P. Protein-energy malnutrition decreases the expression of TLR-4/MD-2 and CD14 receptors in peritoneal macrophages and reduces the synthesis of TNF-alpha in response to lipopolysaccharide (LPS) in mice. Cytokine 2007; 40: 105-114.

15. Bhaskaram P, Sivakumar B. Interleukin-1 in malnutrition. Arch Dis Child 1986; 61: 182-185.

16. Borelli P, Mariano M, Borojevic R. Protein malnutrition: effect on myeloid cell production and mobilization into inflammatory reactions in mice. Nutr Res 1995; 15: 1477-1485.

17. Reeves PG, Nielsen FH, Fahey GC Jr. AIN-93 purified diets for laboratory rodents: final report of the American Institute of Nutrition ad hoc writing committee on the reformulation of the AIN-76A rodent diet. J Nutr 1993; 123: 1939-1951.

18. Ward PG. A micro-Kjeldahl procedure for field use. J Med Lab Technol 1963; 20: 191-195.

19. Dacie JV, Lewis SM. Practical haematology. New York: Churchill Livingstone; 1995.

20. Israels T, van de Wetering MD, Hesseling P, van Geloven N, Caron $\mathrm{HN}$, Molyneux EM. Malnutrition and neutropenia in children treated for Burkitt lymphoma in Malawi. Pediatr Blood Cancer 2009; 53: 47-52.

21. Waterlow JC. Letter: Evolution of kwashiorkor and marasmus. Lancet 1974; 2: 712.

22. Schkenasy A, Jobard P. [Tissular distribution of eosinophilic granulocytes, in the rat made eosinopenic by prolonged protein deficiency]. Nouv Rev Fr Hematol 1961; 1: 202-212.
23. Ahens JW, Raab SO, Haab OP, Mauer AM, Ashenbrucker H, Cartwright GE, et al. Leukokinetic studies. III. The distribution of granulocytes in the blood of normal subjects. J Clin Invest 1961; 40: 159-164.

24. Kampschmidt RF, Upchurch HF. Possible involvement of leukocytic endogenous mediator in granulopoiesis. Proc Soc Exp Biol Med 1977; 155: 89-93.

25. Redl H, Bahrami S, Schlag G, Traber DL. Clinical detection of LPS and animal models of endotoxemia. Immunobiology 1993; 187: 330-345.

26. O'Dea KP, Wilson MR, Dokpesi JO, Wakabayashi K, Tatton $\mathrm{L}$, van Rooijen N, et al. Mobilization and margination of bone marrow Gr-1high monocytes during subclinical endotoxemia predisposes the lungs toward acute injury. J Immunol 2009; 182: $1155-1166$.

27. Fock RA, Xavier JG, Borelli P. Histology alterations in response to lipopolysaccharide (LPS) in a murine model of protein-energy malnutrition. Rev Eletr Farm 2009; 2: 85-101.

28. Khunkaewla P, Schiller HB, Paster W, Leksa V, Cermak L, Andera L, et al. LFA-1-mediated leukocyte adhesion regulated by interaction of CD43 with LFA-1 and CD147. Mol Immunol 2008; 45: 1703-1711.

29. Barja-Fidalgo C, Souza EP, Silva SV, Rodrigues AL, AnjosValotta EA, Sannomyia $P$, et al. Impairment of inflammatory response in adult rats submitted to maternal undernutrition during early lactation: role of insulin and glucocorticoid. Inflamm Res 2003; 52: 470-476.

30. Chandra RK, Kumari S. Nutrition and immunity: an overview. $J$ Nutr 1994; 124: 1433S-1435S.

31. Sixt M, Hallmann R, Wendler O, Scharffetter-Kochanek K, Sorokin LM. Cell adhesion and migration properties of beta 2-integrin negative polymorphonuclear granulocytes on defined extracellular matrix molecules. Relevance for leukocyte extravasation. J Biol Chem 2001; 276: 18878-18887.

32. Carlos TM, Harlan JM. Leukocyte-endothelial adhesion molecules. Blood 1994; 84: 2068-2101.

33. Badolato R. Leukocyte circulation: one-way or round-trip? Lessons from primary immunodeficiency patients. J Leukoc Biol 2004; 76: 1-6.

34. Meager A. Cytokine regulation of cellular adhesion molecule expression in inflammation. Cytokine Growth Factor Rev 1999; 10: 27-39.

35. Auron PE, Webb AC. Interleukin-1: a gene expression system regulated at multiple levels. Eur Cytokine Netw 1994; 5: 573592.

36. Watson RW, Redmond HP, Bouchier-Hayes D. Role of endotoxin in mononuclear phagocyte-mediated inflammatory responses. J Leukoc Biol 1994; 56: 95-103.

37. Yang CM, Luo SF, Hsieh HL, Chi PL, Lin CC, Wu CC, et al. Interleukin-1beta induces ICAM-1 expression enhancing leukocyte adhesion in human rheumatoid arthritis synovial fibroblasts: involvement of ERK, JNK, AP-1, and NF-kappaB. J Cell Physiol 2010; 224: 516-526.

38. Fock RA, Vinolo MA, Crisma AR, Nakajima K, Rogero MM, Borelli P. Protein-energy malnutrition modifies the production of interleukin-10 in response to lipopolysaccharide (LPS) in a murine model. J Nutr Sci Vitaminol 2008; 54: 371-377.

39. Glauser MP, Zanetti G, Baumgartner JD, Cohen J. Septic shock: pathogenesis. Lancet 1991; 338: 732-736. 